\title{
The Influence of the Use of Cement Brands on the Physical and Mechanical Properties of Reactive Powder Concrete (RPC)
}

\author{
E. Sutandar*, Setya Budi and F. Juniardi \\ Faculty of Civil Engineering, University of Tanjungpura, \\ Prof. Dr. Hadari Nawawi Pontianak street, West Kalimantan, Indonesia. \\ E-mail: Erwin_sutandar@yahoo.com; gatotsetyabudi@civil.untan.ac.id; \\ ferry_juniar_di@yahoo.com \\ *Corresponding author details: Erwin sutandar; Erwin_sutandar@yahoo.com
}

\begin{abstract}
The most popular building material today is concrete. Concrete is used for buildings, industrial structures, bridges, railroad sleepers, roads, dams and more. Along with the development of concrete technology is increasingly developing and innovative so as to achieve better characteristics, cheaper prices and environmentally friendly. In the early days of the development of concrete it is explained to us about the origin from ancient times to civilization to the present century of its development. In current developments, concrete already has a very high compressive strength up to 200-800 MPa, this is also called Ultra Hight Concrete (UHC). It is developed by the Reactive Powder concrete (RPC) method. Where in the research conducted, the manufacture of reactive material, namely Reactive Powder concrete (RPC) was given with a compressive strength of up to $52 \mathrm{MPa}$. The components of the RPC mixture consist of cement, fine aggregate, silica fume, superplasticizer and water. To produce a compressive strength of $52 \mathrm{MPa}$, the composition of the mixture used previous research. Detailed RPC concrete mix proportions are given in this study. Preparation and testing of materials are made in the laboratory of the Faculty of Civil Engineering in Untan. The results that will be obtained are the physical and mechanical properties of RPC Concrete. As previously explained, the manufacture of RPC concrete requires basic ingredients that include cement, fine aggregate, silica fume, superplasticizer and water mixed together. Of course, with basic ingredients with good and correct composition, the physical and mechanical properties of RPC concrete will reach the planned quality. Cement sold in the market today has PPC and PCC types. Therefore, the cement which is a binder of powder materials into a solid one plays a very important role in the formation of the best physical and mechanical properties of RPC concrete. With cement as a binding material, it is certain that the strength of RPC concrete is determined by the binding capacity of the type of cement to be used, thus RPC concrete will be obtained according to the planned quality of the plan. From the cement brands on the Indonesian market consisting of PPC and PCC cement types, it can be concluded that one of the cements using the PCC type cement brand has better physical and mechanical properties than the PPC type cement brand. And all brands of cement with PCC type produce compressive strength > $52 \mathrm{MPa}$. So, in the manufacture of RPC concrete it is recommended to use a cement brand with PCC type.
\end{abstract}

Keywords: Concrete; Reactive Powder concrete; Cement Brand; Physical and Mechanical Properties; Cement Type; PCC and PPC.

\section{INTRODUCTION}

Concrete is a building construction material that is widely used today. This is because concrete has several advantages when compared to other construction materials, which are strong in resisting compressive forces, resistant to weather changes and resistant to high temperatures. The strength of concrete is highly dependent on the constituent material. The main materials for making concrete consist of coarse aggregate, fine aggregate, and cement.

Around 1950 concrete with a compressive strength of 40 MPa was produced, and in 1960 High Performance Concrete (HPC) was created. High Strength Concrete (HPC) is the name given to a class of material that exhibits properties superior to conventional concrete. The advantages of her lie on one or more physical properties and mechanical, such as strength, stiffness, durability, or resistance to chemical attack. The material used to make this HPC is determined based on established regulations. From 1970, the resulting compressive strength ranged from $50 \mathrm{MPa}$ to $100 \mathrm{MPa}$.

Around 1990, Reactive Powder Concrete (RPC) appeared. Its compressive strength goes up to $800 \mathrm{MPa}$. While HPC is increasingly being used for bridges, RPC is still very rarely used, this is because RPC technology is still developing and needs further research.

RPC concrete is made of material in the form of powder (powder) so that they interact with each other. With a perfect reaction will produce concrete that has the best physical and mechanical properties and in accordance with the plan.

Cement as one of the basic ingredients for making RPC concrete is a material that binds powder materials into one solid. 
With the type of cement as a binder, it is certain that the physical and mechanical properties of RPC concrete are largely determined by the binding capacity of the type of cement to be used.

With the development of increasingly advanced technology, normal concrete to high-strength concrete has been produced according to the needs in the field. Researches were also developed to obtain very high-quality concrete and also with the materials to be used.

In the early 1990s in France, one of the newest breakthroughs in the field of concrete material technology was the introduction of reactive powder concrete (RPC), or reactive powder concrete. RPC has the characteristics of high compressive strength, ductility and durability. Properties that have been produced in the HDR Bouygues laboratory are in the form of compressive strengths reaching 200-800 MPa (Richard, 1996). RPC is still very rarely used; this is because RPC technology is still developing and needs further research.

RPC concrete uses materials with fine particles that are useful for minimizing empty voids, so that the concrete becomes denser and stronger, because the materials that make up RPC concrete are smooth so that they interact with one another. The weight of the RPC produced is lighter than normal concrete because RPC does not use coarse aggregate or stone. Based on RSNI 2847:2018 normal concrete weight ranges from 2320 to $2400 \mathrm{~kg} / \mathrm{m} 3$, while the results of research conducted by Richard and Cheyrezy (1994: 6) RPC concrete has a weight ranging from 1900 to $2100 \mathrm{~kg} / \mathrm{m} 3$. Because it is made from aggregates of micro materials, the finished concrete has homogeneity, compactness and high durability. RPC containing micro materials, one of which is silica, is also able to react at higher temperatures in the manufacturing process, so that it can accelerate the increase in the compressive strength of concrete. With this series of advantages, RPC can be made with a smaller and thinner cross-section without reinforcement. RPC can also be used for the manufacture of architectural precast.

This study aims to determine the physical and mechanical properties that can be achieved by using quartz sand and river sand as a mixture of RPC concrete. So, this research can be used as infrastructure development by utilizing sand, quartz and sand rivers in Kalimantan Barat.

\section{METHODOLOGY}

The method used to find out something by going through systematic steps to test the hypothesis, it must be done by testing the RPC concrete material and making the RPC test object which is then tested, which later the results can be used for testing the hypothesis, where testing is carried out based on regulations that applies.

This research study is divided into 2 (two) parts, namely: 1. Study of literature

2. Experimental Study

Where the study of literature aims to examine the relationship between the variables to be studied, by studying existing theories and how to collect data. Through library research, research hypotheses will be born which are temporary answers to existing problems.

This experimental study was carried out in a laboratory by making a number of test objects to be tested so that the necessary data were obtained, after the data were analyzed it could be used to test the hypothesis a so that a conclusion was obtained.
This study will examine RPC concrete with a comparison of variations in the type of cement, then the type of cement is the best and in accordance with the final goal of this research, namely to produce the best RPC concrete and according to the compressive strength plan.

\section{MATERIAL}

\section{Cement}

This is done by visual inspection of the cement used, namely cement PCC and PPC which has met the Indonesian National Standard (SNI 15-7064-2004 and 15- 0302 2004)

\section{Fine Aggregate (Quartz Sand)}

The sand that contains a lot of quartz minerals (quartz) is called quartz sand. Quartz sand-forming minerals are predominantly composed of quartz crystals (SiO2). The sand used in this study is sand from Kec. District Mandor. Ladak Hedgehog district.

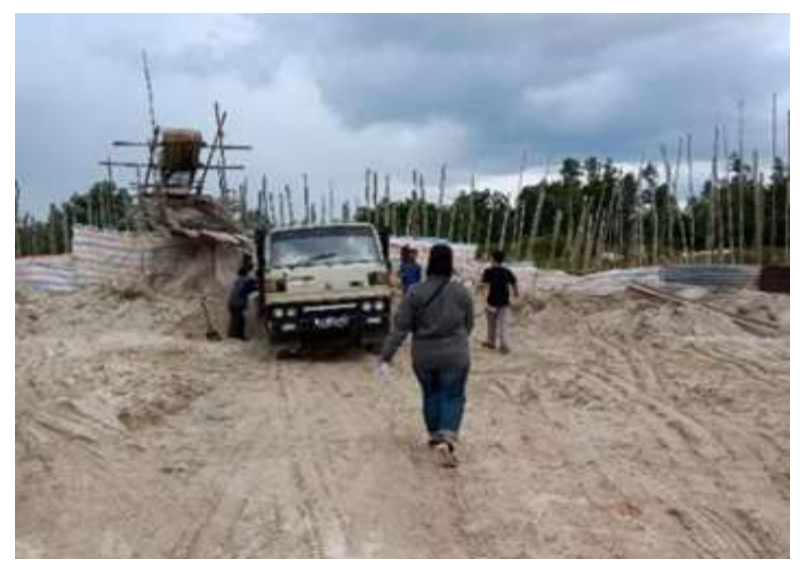

FIGURE 1: Quartz Sand Mine, Kec. District Mandor. West Kalimantan Landak

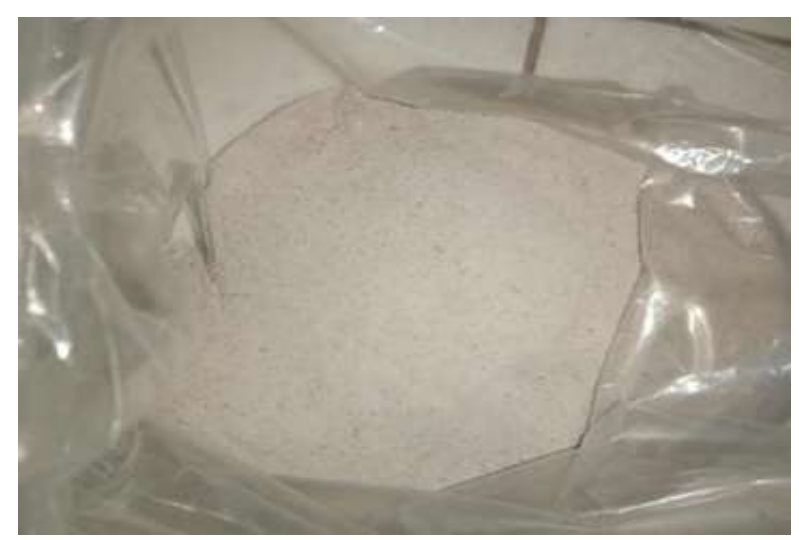

FIGURE 2: Quartz Sand

TABLE 1: Chemical Composition of Quartz Sand in the Mandor Area

\begin{tabular}{|c|c|}
\hline Jenis Unsur (\%) & Komposisi (\%) \\
\hline $\mathrm{SiO}_{2}$ & 87.293 \\
\hline
\end{tabular}

Source: Technical Implementation Unit of Construction Materials Laboratory, Department of Public Works and Spatial Planning, West Kalimantan Province

\section{Water}

The water used is a type of clean water that meets the physical requirements, visually and chemically, where the water used must be clean according to SNI 03 - 2847 2002. 


\section{Superplasticizer}

Superplasticier used for research is that Sikament-LN production Sica, which serves to increase the workability of the concrete or can be called as a diluent concrete.

\section{Silica Fume}

Silica fume is a additives were very good and highly efficient for concrete, in the aim of producing concrete with the power frequency.

\section{Population and Sample}

This study used a cylindrical test object with a size of $15 \mathrm{~cm}$ $\mathrm{x} 30 \mathrm{~cm}$ and $10 \mathrm{~cm} \times 20 \mathrm{~cm}$.

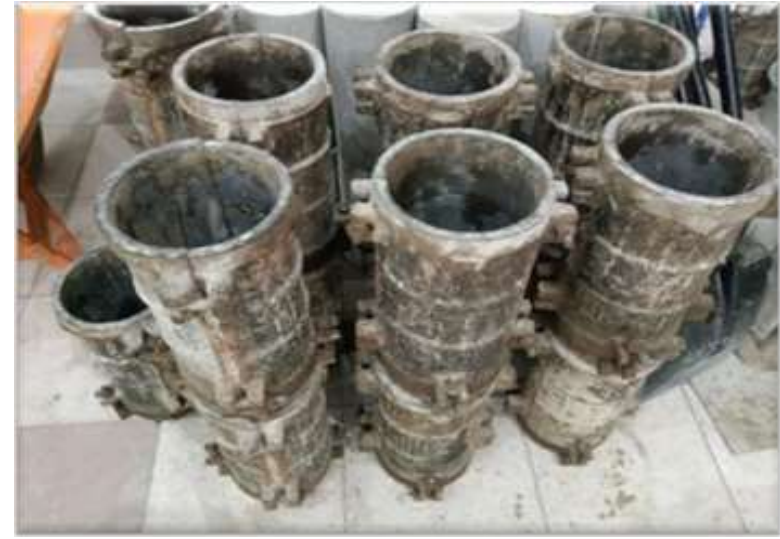

FIGURE 3: Cylinder Mold

TABBLE 2: Sample List of Test Items

\begin{tabular}{|c|c|c|c|c|c|c|c|c|}
\hline \multirow{4}{*}{ No } & \multirow{4}{*}{ Sample } & \multicolumn{7}{|c|}{ Cylindrical Test Object } \\
\hline & & \multicolumn{5}{|c|}{ Amount of Sample } & $\begin{array}{c}\text { Tensile } \\
\text { Test } \\
\end{array}$ & $\begin{array}{c}\text { Modulus of } \\
\text { Elasticity }\end{array}$ \\
\hline & & \multicolumn{5}{|c|}{ Days too } & Days too & Days too \\
\hline & & 3 & 7 & 14 & 21 & 28 & 28 & 28 \\
\hline 1 & V1 (PCC Holcim) & 15 & 15 & 15 & 15 & 15 & 6 & 6 \\
\hline 2 & V2 (PCC Conch) & 15 & 15 & 15 & 15 & 15 & 6 & 6 \\
\hline 3 & V3 (PCC 3 Roda) & 15 & 15 & 15 & 15 & 15 & 6 & 6 \\
\hline 4 & V4 (PCC Gersik) & 15 & 15 & 15 & 15 & 15 & 6 & 6 \\
\hline 5 & V5 (PPC Puger) & 15 & 15 & 15 & 15 & 15 & 6 & 6 \\
\hline \multicolumn{2}{|c|}{ Total } & \multicolumn{5}{|c|}{375} & \multicolumn{2}{|c|}{60} \\
\hline
\end{tabular}

\section{Material Inspection}

Inspection of materials as follows:

\section{Cement}

This inspection is carried out visually on the cement used, namely PCC and PPC cement which have met the Indonesian National Standard (SNI 15-7064-2004 and 15-0302-2004).

Fine Aggregate (Quartz Sand)

For sand inspection includes:

- Examination of Organic Content in Sand Aggregate

- Checking Sludge Aggregate, Sand Content

- Checking the Moisture Content of Sand Aggregate

- Sand Aggregate Gradation Inspection

- Specific Gravity and Water Absorption of Sand Aggregate

- Inspection of Weight, Volume Fine Aggregate Sand

Water

The water used is from the Regional Drinking Water Company (PDAM) taken at Jalan Perdana no 257 where light bricks are made. However, in this study, the chemical content of water was not investigated.

\section{Superplasticizer}

This inspection is carried out visually and by examining the composition of the brochure which is planned to use the LN type of cycle.

\section{Silica Fume}

This inspection is carried out visually and by reviewing the composition of the existing brochure. With a composition based on previous research.
RPC Concrete Testing

Tests carried out concrete include:

- Slump Test

- Volume Weight Test

- Compressive Strength Test

- Tenstile Test

- Elasticity Modulus Test

\section{Mixed Composition}

TABLE 3: Composition of the basic materials of Samples

\begin{tabular}{|c|c|}
\hline Material & Berat $\left(\mathbf{k g} / \mathbf{m}^{\mathbf{3}}\right)$ \\
\hline Cement & 935 \\
\hline Water & 262 \\
\hline Quartz sand & 1,040 \\
\hline Superplasticizer & 4.675 \\
\hline Silica Fume & 234 \\
\hline w/c & 0.26 \\
\hline
\end{tabular}

\section{THE RESULTS AND DISCUSSION}

\section{Quartz Sand}

Minerals are non-renewable resources and generally contain more than one valuable mineral, in addition to the main mineral, the associated minerals may also be of economic value to cultivate. Landak Regency is rich in potential mineral resources, especially alluvial gold deposits whose mining is carried out by the people in the Mandor River watershed. Gold alluvial deposits generally contain associated minerals such as: Titanium dioxide (TiO2), magnetite (Fe2Ti04), zircon ( $\mathrm{ZrSiO} 4)$, and others. 
These associated minerals contain rare earth elements (UTJ) and at present their use can improve the quality of industrial products of metal, information, electronics, oil and gas and nuclear energy development, so that the world market demand for UTJ is increasing.

Quartz sand is a fine aggregate used as an admixture in the manufacture of RPC concrete. The quartz sand used is sand from the Mandor of West Kalimantan. The color of this fine aggregate is white. The research location is in the District of Mandor and District of Jamin, District of Landak, West Kalimantan Province. Geographically at coordinates 1090 18' 48.6" - 1090 25' 36.5" East Longitude and 000 26' 10.5" - 00013 ' 33.5" South Latitude

Landak Regency is rich and diverse in potential mineral resources, especially alluvial gold, whose mining is carried out by PETI and is located in the S. Mandor watershed. In addition to gold minerals, there are zircon minerals that have been mined and exported to China. Zircon is one of the associated minerals found in alluvial gold ore deposits. The results of the exploration of PT Mitra Romarim, 2012, the characteristics of zircon are located in the Mining Block with an area of 1, $053 \mathrm{Ha}$ in Paritukong Village, Mandor District, namely the roundness level reaches $40 \%$, the degree of sorting or sorting of zircon minerals has a medium level with a grain size distribution of $50 \%$ measuring $2 \mathrm{~mm}$ and $50 \%$ is $0.1 \mathrm{~mm}$ in size.

Alluvial gold mining in the Mandor area was first carried out by the Chinese in 1745 and was followed by local people and immigrants. In the past, people mined gold by scratching sand for sand at the bottom of the river using simple wooden trays. Along with the development of the people's gold mining (PETI) using dongpeng machines. PETI mining activities are carried out in the Mandor River watershed starting from the upstream (Menjalin) to the mouth of the Mandor River (Sungai Tengkorak). Field observations of the current condition of the Mandor River basin are in the form of the tailings deposits from previous alluvial gold mining. The tailings deposit is megascopically in the form of grayish-white quartz sand, fine-grained, medium to coarse mixed with clay, and some of it becomes land for oil palm plantations. The distribution of taking deposits in the study area is divided into 2 blocks, namely the Jamlin Block and the Mandor Block, the distribution area of the tailings deposit is 3,209 Ha., and the Mandor Block is 3,514.7 Ha., (Rohmana et al., 2013).

The results of the mineralogy analysis of grains identified a higher percentage of quartz minerals in each drill hole. Quartz in the study area is in the form of sand contained in the distribution of alluvial deposits which are currently in the form of smallholder gold mining tailings. Tailings in the study area are quartz sand mixed with clay. Quartz sand is gray-white in color, fine-medium to coarse-grained and there are components of igneous rock and greenish-white clay. Calculation of the quartz sand resource is carried out by multiplying the total depth of each borehole point by the area of influence of each borehole point and multiplying by the specific gravity of the quartz.
The results of the calculation of the quartz inferred resources in each research location are as follows: The amount of quartz sand resources in the Lima-Lima Region, Mandor is 5,245,400 tons, the area of influence is 322,290 $\mathrm{m} 2(32.23 \mathrm{Ha})$, the amount of quartz resources in the Hamlet Lonjengan 1, Sepahat Village, Melinating 150,000 tons, the area of influence is $10,000 \mathrm{~m} 2(1 \mathrm{Ha})$, The amount of quartz resources in Lonjengan 2 Hamlet, Sepahat Village, Melin is 1,621,138 tons, the area of influence is $79,107 \mathrm{~m} 2(7,91 \mathrm{Ha})$, Quartz sand in the study area is very abundant and generally it is relatively clean from impurities in the form of soil and clay, because it has undergone a leaching process during gold mining. The use of quartz sand at this time by local residents is used as a raw material for buildings.

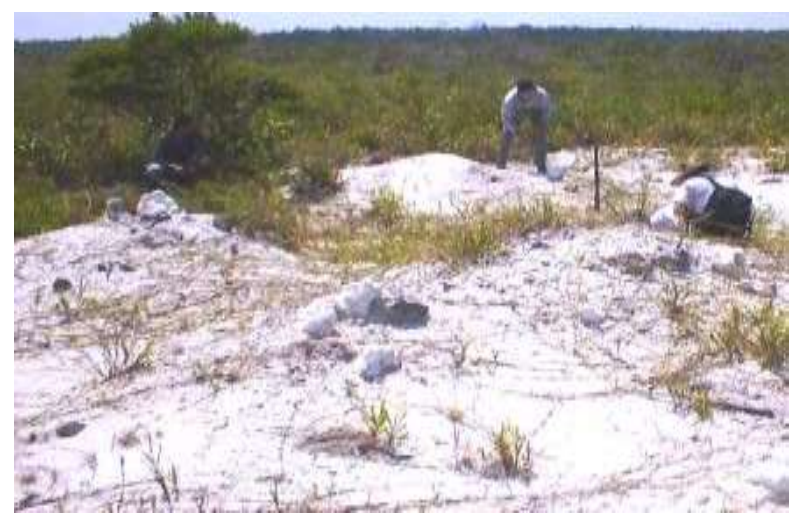

FIGURE 4: Quartz Ground in Mandor

TABLE 4: Results of Chemical Analysis of Quartz Sand Samples

\begin{tabular}{|l|c|c|}
\hline \multicolumn{3}{|c|}{ Chemical Analysis of Quartz Sand } \\
\hline Element Type & Mandor City & $\begin{array}{c}\text { Riverside } \\
\text { Mandor }\end{array}$ \\
\hline $\mathrm{SiO}_{2} \%$ & 98.6 & 98.8 \\
\hline $\mathrm{AL}_{2} \mathrm{O}_{3} \%$ & 0.51 & 0.29 \\
\hline $\mathrm{Fe}_{2} \mathrm{O}_{3} \%$ & 0.25 & 0.25 \\
\hline $\mathrm{TiO}_{2} \%$ & 0.18 & 0.15 \\
\hline $\mathrm{CaO}_{0} \%$ & 0.21 & 0.21 \\
\hline $\mathrm{K}_{2} \mathrm{O} \%$ & 0.012 & 0.028 \\
\hline $\mathrm{MgO} \%$ & - & - \\
\hline $\mathrm{CaO}$ freely \% & - & - \\
\hline $\mathrm{H} 2 \mathrm{O} \%$ & - & - \\
\hline
\end{tabular}

\section{Gradation of Fine Aggregate}

The sand zone planning used in this study is sand in zone 4 , namely the fine category. The analysis of the fine aggregate gradation obtained is as follows: 
TABLE 5: Analysis of Fine Aggregate Gradation

\begin{tabular}{|c|c|c|c|c|c|c|}
\hline \multirow{2}{*}{ No } & \multirow{2}{*}{$\begin{array}{c}\text { Container } \\
\text { Weight }\end{array}$} & \multirow{2}{*}{$\begin{array}{l}\text { Weight of Container } \\
\text { + Test Object }\end{array}$} & \multicolumn{2}{|c|}{ Weight Hold } & \multicolumn{2}{|c|}{ Cumulative (\%) } \\
\hline & & & (grams) & $(\%)$ & Stuck & Passes \\
\hline 9.5 & 541.900 & 541.900 & 0.000 & 0.000 & 0.000 & 100.000 \\
\hline 4.8 & 509.300 & 509.300 & 0.000 & 0.000 & 0.000 & 100.000 \\
\hline 2.38 & 491.600 & 491.600 & 0.000 & 0.000 & 0.000 & 100.000 \\
\hline 1.18 & 458.000 & 461.600 & 3.600 & 0,180 & 0.180 & 99.820 \\
\hline 0.59 & 419.600 & 512.100 & 92.500 & 4.625 & 4.805 & 95.195 \\
\hline 0.297 & 390.300 & 2242.800 & 1852.500 & 92.625 & 97.430 & 2.570 \\
\hline 0.149 & 374.900 & 383.900 & 7.200 & 0.360 & 97.790 & 2.210 \\
\hline Pan & 348.500 & 392.700 & 44.200 & 2.210 & 100 & 0.000 \\
\hline Jumlah & 2000.000 & 100.000 & 200.205 & & & \\
\hline \multicolumn{3}{|c|}{ Fine Modulus } & 2.002 & & & \\
\hline
\end{tabular}

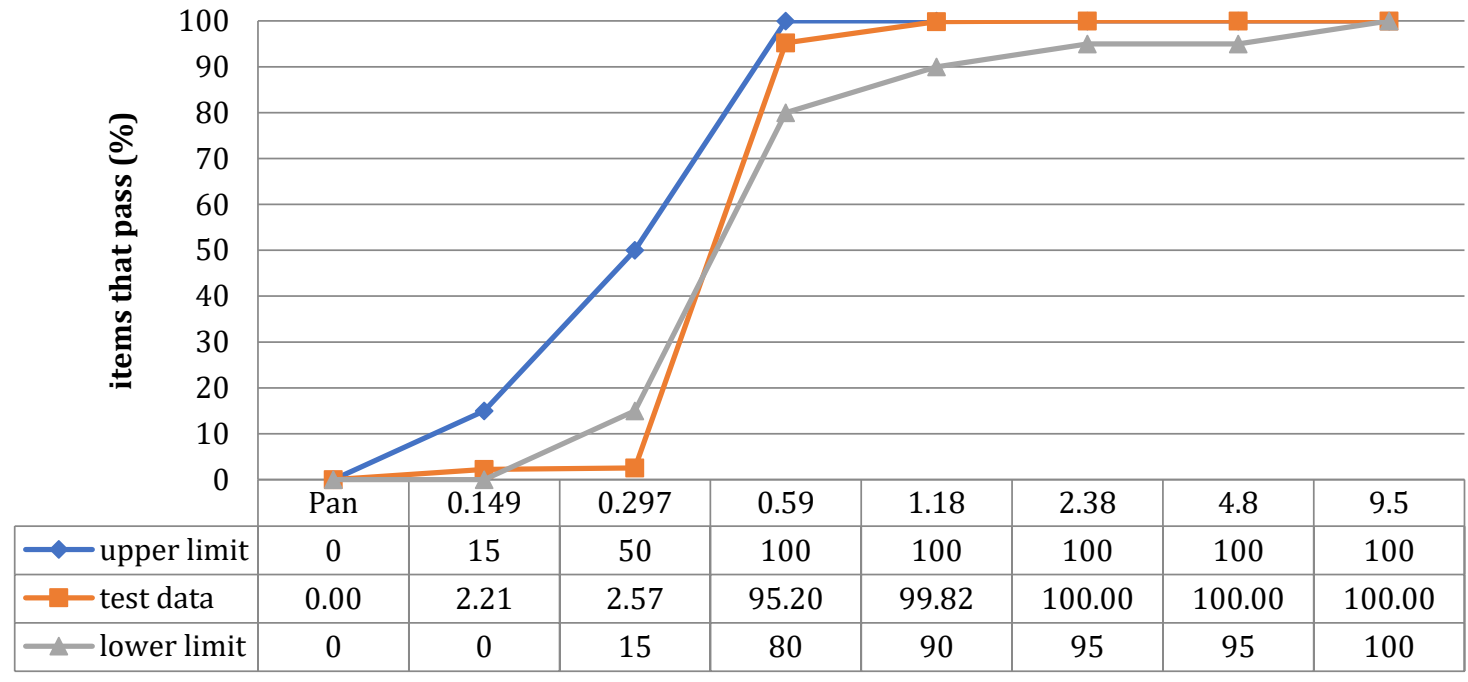

FIGURE 5: Fine Sand Gradation

Quartz sand gradation zone obtained from the analysis can still be said to be zone 4 according to the plan. This study uses fine aggregate which is useful for minimizing empty voids between grains/particles so that a very dense concrete is obtained.

Your paper must be in two column format with a space of 0.27 " between columns.

\section{Specific Gravity and Water Absorption}

The type of aggregate is distinguished in two states, namely the saturated surface dry state (SSD) and the absolute dry state or oven dry state. In this examination, the absorption value will also be obtained, namely the ratio between the weight of water absorbed by the aggregate in a saturated surface condition and the weight of the aggregate in an oven dry state.

Specific gravity inspection aims to determine the specific gravity and percentage of water weight that can be absorbed by fine aggregate (sand), calculated against dry weight. Examination of the specific gravity of sand produces 3 types of specific gravity, namely dry density, saturated surface dry density (SSD) and wet density. The results can be seen in the table below:
TABLE 6: Calculation of Data Analysis of Quartz Sand Density

\begin{tabular}{|c|c|c|}
\hline 1 & Apparent specific gravity & $2.587 \mathrm{Kg} / \mathrm{m} 3$ \\
\hline 2 & $\begin{array}{c}\text { Specific gravity dry } \\
\text { condition (dry bulk) }\end{array}$ & $2.567 \mathrm{Kg} / \mathrm{m} 3$ \\
\hline 3 & $\begin{array}{c}\text { SSD dry condition, density } \\
\text { (bulk SSD) }\end{array}$ & $2.575 \mathrm{Kg} / \mathrm{m} 3$ \\
\hline 4 & $\begin{array}{c}\text { Percentage of water } \\
\text { absorption }\end{array}$ & $0.300 \%$ \\
\hline
\end{tabular}

\section{Weight Volume Fine Aggregate Quartz Sand}

Examination of the weight of the volume of sand is carried out in the loose and solid state. The weight analysis of the quartz sand volume obtained is as follows:

TABLE 7: Calculation of Data Analysis of Quartz Sand Volume Weight

\begin{tabular}{|c|c|c|c|c|}
\hline 1 & $\begin{array}{l}\text { Contents Weight } \\
\text { Loose Condition }\end{array}$ & $=$ & 1.5333 & $\mathrm{~kg} /$ Liter \\
\hline 2 & Solid State Weight & $=$ & 1,716 & Kg/liter \\
\hline 3 & $\begin{array}{l}\text { Fill Weight Solid } \\
\text { Condition }\end{array}$ & $=$ & 1.760 & kg/Liter \\
\hline
\end{tabular}




\section{Organic Content in Fine Aggregate of Quartz Sand}

Examination of the organic content contained in the fine aggregate (sand) of all gradations by soaking the sand in $3 \% \mathrm{NaOH}$ liquid for 24 hours. Then compare the results with the organic plate. From the observation of the color of the liquid after 24 hours, the color of the liquid was obtained according to the standard color No. 3. This means that the organic matter contained in the sand does not exceed the tolerance (standard color No. 3). The results of observations of organic levels in quartz sand can be seen in the appendix.

\section{Quartz Sand Fine Aggregate Sludge Content}

Examination of the mud content in the sand is carried out to find out how much mud content is in the sand. Because the silt content can cause less perfect bonding of cement paste with aggregate. Analysis of the levels of quartz sand, mud obtained are as follows:

TABLE 8: Analysis of Quartz Sand Mud Content

\begin{tabular}{|c|c|}
\hline Sand mud content & $2.88 \%$ \\
\hline
\end{tabular}

From the results of the study it was found that the content of mud contained in the sand was $2.88 \%$. From the results obtained, it can be concluded that the mud content in the sand is less than $5 \%$, this means that it is still suitable for use in RPC concrete mixtures.

\section{Moisture Content of Fine Aggregate of Quartz Sand}

Inspection of aggregate moisture content is carried out to determine the water content in fine aggregate (sand) which will later be used in the RPC concrete mixture.

TABEL 9: Moisture Content

\begin{tabular}{|l|l|}
\hline Moisture Content & $4.55 \%$ \\
\hline
\end{tabular}

From the table above, the water content of the sand used for the RPC concrete brick mixture is $4.55 \%$

\section{Cement}

While the elements contained in the PCC and PPC cement brands used can be seen in the following table:

TABLE 10: Cement Element Composition

\begin{tabular}{|c|c|c|c|c|c|}
\hline \multirow{3}{*}{ Element } & \multicolumn{5}{|c|}{ Brands } \\
\hline & Holcim (PCC) & Tiga Roda (PCC) & Puger (PPC) & Gersik (PCC) & Conch (PCC) \\
\hline & $\%$ & $\%$ & $\%$ & $\%$ & $\%$ \\
\hline Silicon dioxide $\left(\mathrm{SiO}_{2}\right)$ & 23.04 & 20.75 & 20.84 & 22.04 & 23.64 \\
\hline Aluminium Oksida $\left(\mathrm{Al}_{2} \mathrm{O}_{3}\right)$ & 7.40 & 5.11 & 7.10 & 5.40 & 8.40 \\
\hline Ferric oxide $\left(\mathrm{Fe}_{2} \mathrm{O}_{3}\right)$ & 3.36 & 3.17 & 5.38 & 3.26 & 4.36 \\
\hline Calcium Oksida (CaO) & 57.38 & 64.39 & 60.63 & 51.38 & 58.38 \\
\hline Magnesium oxide (Mg0) & 1.91 & Max 6 & 0.70 & 1.91 & 1.91 \\
\hline Sulfur Trioksida $\left(\mathrm{SO}_{3}\right)$ & 2.0 & - & 1.99 & 2.0 & 2.0 \\
\hline Lost Incand (Lo1) & 3.94 & - & 3.04 & 2.94 & 3.28 \\
\hline Free calcium oxide & 0.56 & 0.76 & 0.86 & 0.56 & 0.56 \\
\hline Insoluble Part & 10.96 & - & 3.19 & 6.96 & 8.96 \\
\hline Total alkali (Na2O) & - & 0.39 & 0.52 & - & - \\
\hline
\end{tabular}

\section{Water}

The water used is PDAM water with a PH of $6-7$ and clean conditions because the water can be used for drinking water. So, it can be concluded that the water has met the standards and can be used for mixing in the manufacture of RPC concrete.

\section{Chemical Admixture}

Chemical admixtures are usually used in small amounts in RPC concrete mixes. The purpose of its use is to improve certain properties of the mixture, especially to speed up the drying process in RPC concrete.

In the study, Sikamen LN was used as a chemical admixture to reduce the water level of concrete, specifically formulated for the precast concrete element industry, to increase the initial strength of the concrete so that the formwork can be released quickly and can be used as much as possible so that the time used can be accelerated. So, from these data it can be concluded that Sikamen LN is a type $\mathrm{F}$ chemical admixture with high initial strength and water reduction.

Sikamen LN is a dark brown liquid from PT Sika Indonesia. By using Sikaman LN will be able to earn my water up to $20 \%$, will result in an increase of $40 \%$ in 28 days compressive strength and increased water-resistance. Its specific gravity is $1.22 \pm 0.01 \mathrm{~kg} / \mathrm{L}$ at $2+20^{\circ} \mathrm{C}$.

While the usage limit of Sikamen LN is at a dose level of $0.30 \%-2.0 \%$ of the total weight of the cement material depending on the requirements for workability and strength. It is recommended that a trial mix be carried out to determine the exact dose level required. Typical dosage levels for use with silica sand are $0.30 \%-1.20 \%$ by weight of cementitious materials.

\section{Silica Fume}

Sika fume used is a product of PT. Sika is a powder with a gray color. SikaFume is used in shotcrete, structural concrete, precast concrete and other areas of concrete construction where high demands are placed on quality fresh and fast hardening concrete.

SikaFume containing solid ka dioxide dioxide is very smooth and very reactive. The presence of this substance provides excellent internal cohesion and water retention in fresh concrete. The concrete becomes highly pliable and the permeability is substantially improved. In hardened concrete, the later reactive silica fume forms chemical bonds with free lime $\left(\mathrm{CaOH}_{2}\right)$. 
The hydration product formation additive results in a significantly denser cement matrix. With the use of SikaFume concrete will show the following properties:

- High stability of environmentally friendly concrete

- Greatly increased durability

- Excellent salt resistance and de-icing if any air entraining agent is used at the same time

- Ultimate power increase

- Improved abrasion resistance

- Improved water, abrasion resistance

- Increased viscosity of gas

- Reduces chloride penetration

SikaFume does not contain chlorides or other steel corrosion- inducing agents, and therefore can be used without limitation for pre-stressed concrete construction. With a specific gravity of $0.65 \mathrm{~kg} / \mathrm{l}$ and chloride ions $<0.3$ $\mathrm{M} \%$. Use with a dose of $5-10 \%$ of the weight of semen

\section{Analysis of Reactive Powder Concrete (RPC)}

RPC concrete is the final subject of this research. The RPC concrete research used cylindrical specimens with dimensions of $100 \times 200 \mathrm{~mm}$ and $150 \times 300 \mathrm{~mm}$. The material composition plan was obtained from previous research, namely from journal materials using water per binder $(\mathrm{w} / \mathrm{c}$ ) of 0.28 . The cylindrical concrete mix design uses different types of cement, namely PPC and PCC. The independent variable used is the type of cement used.

\section{Slump Test}

Slump testing is very important to determine the level of workability and the resulting material. Where the slump test is carried out. The data from the research that obtains the following data:

TABLE 11: Slump Test

\begin{tabular}{|c|c|c|}
\hline No & Sample & Slump Test (cm) \\
\hline 1 & V1 (PCC Holcim) & 5.0 \\
\hline 2 & V2 (PCC Conch) & 4.5 \\
\hline 3 & V3 (PCC 3 Roda) & 4.5 \\
\hline 4 & V4 (PCC Gersik) & 5.0 \\
\hline 5 & V5 (PPC Puger) & 4.8 \\
\hline
\end{tabular}

From the table it can be seen that for the slump test, an average of $5 \mathrm{~cm}$ is obtained, this means that the mixture of Variations 1 to 5 has a low or a viscous level of workability.

\section{Volume/Fill Weight Test}

The results of the average volume/content weight of RPC concrete bricks that have been tested for a sample size of $150 \mathrm{~mm} \times 300 \mathrm{~mm}$ of each type of cement for each age obtained the following data:

TABLE 12: Volume/Fill Weight

\begin{tabular}{|c|c|c|c|c|c|c|}
\hline \multirow{2}{*}{ No } & \multirow{2}{*}{ Sample } & \multicolumn{5}{|c|}{ Volume Weight (Kg/m $\mathbf{~ / d a y ) ~}$} \\
\cline { 3 - 7 } & & $\mathbf{3}$ & $\mathbf{7}$ & $\mathbf{1 4}$ & $\mathbf{2 1}$ & $\mathbf{2 8}$ \\
\hline 1 & V1 (PCC Holcim) & $2,077.531$ & $2,075.017$ & $2,080.359$ & $1,969.428$ & $2,080.359$ \\
\hline 2 & V2 (PCC Conch) & $2,054.905$ & $2,063.075$ & $2,063.704$ & $2,065.589$ & $2,066.218$ \\
\hline 3 & V3 (PCC 3 Roda) & $2,033.850$ & $2,048.620$ & $2,052.391$ & $2,057.104$ & $2,077.217$ \\
\hline 4 & V4 (PCC Gersik) & $2,101.728$ & $2,110.842$ & $2,112.413$ & $2,125.926$ & $2,129.383$ \\
\hline 5 & V5 (PPC Puger) & $2,054.905$ & $2,063.075$ & $2,063.704$ & $2,066.218$ & $2,066.218$ \\
\hline
\end{tabular}

$\square$ Semen Holcim $\quad \square$ Semen Conch $\quad \square$ Semen Tiga Roda $\quad \square$ Semen Puger

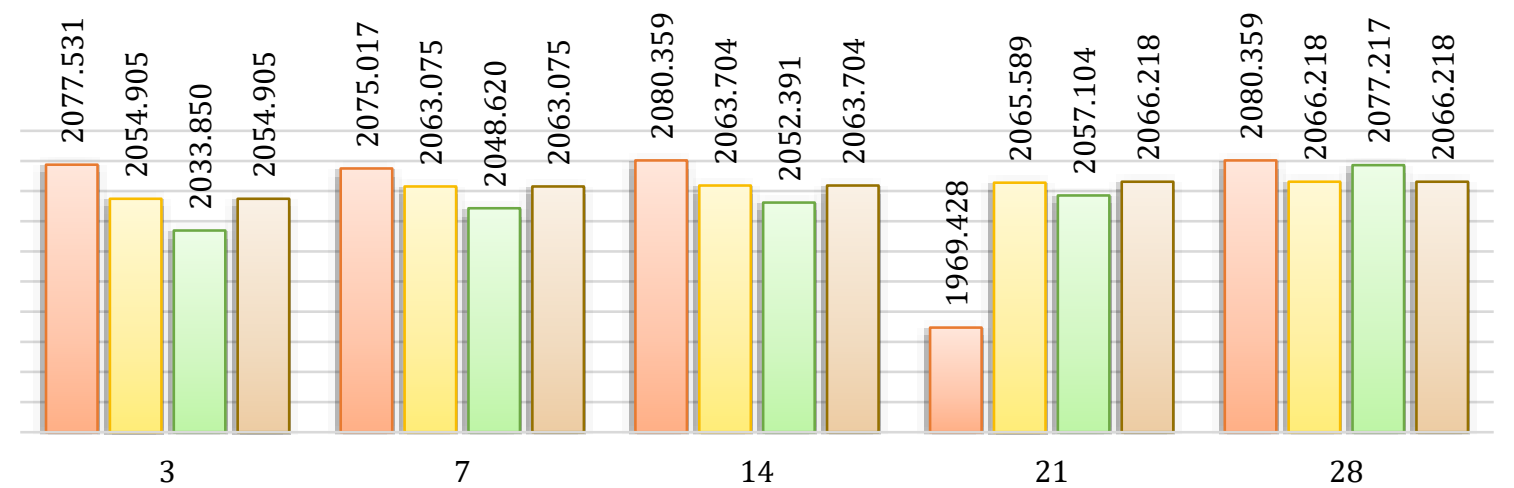

FIGURE 6: The relationship between the average compressive strength and age

From the table, it can be seen that the RPC concrete from each variation was taken from 15 samples that had been made, which resulted in an average weight/volume weight of RPC concrete between $2000-2200 \mathrm{~kg} / \mathrm{cm}^{3}$. It can be seen from this that the weight of RPC concrete is lighter than normal concrete in general $\left(2400 \mathrm{~kg} / \mathrm{cm}^{3}\right)$ and also all variations of its volume, weight from 3 days to 28 days, it turns out that the volume weight of the concrete is increasing.

\section{Compressive Strength Test}

The results of the compressive strength test of RPC concrete that have been tested for a sample size of $150 \mathrm{~mm}$ x $300 \mathrm{~mm}$ from testing 15 samples per each variable for each age obtained the following data: 
TABLE 13: Average Compressive Strength of each variation Vs Age

\begin{tabular}{|c|c|c|c|c|c|}
\hline \multirow{2}{*}{ Sample } & \multicolumn{5}{|c|}{ Average Compressive Strength (Days) (MPa) } \\
\cline { 2 - 6 } & $\mathbf{3}$ & $\mathbf{7}$ & $\mathbf{1 4}$ & $\mathbf{2 1}$ & $\mathbf{2 8}$ \\
\hline V1 (PCC Holcim) & 38.626 & 49.381 & 56.134 & 59.030 & 58.930 \\
\hline V2 (PCC Conch) & 34.335 & 47.389 & 58.280 & 58.132 & 67.907 \\
\hline V3 (PCC 3 Roda) & 34.862 & 40.064 & 45.817 & 51.550 & 52.229 \\
\hline V4 (PCC Gersik) & 36.761 & 47.431 & 54.352 & 56.348 & 57.113 \\
\hline V5 (PPC Puger) & 26.200 & 33.885 & 38.854 & 40.892 & 41.811 \\
\hline
\end{tabular}

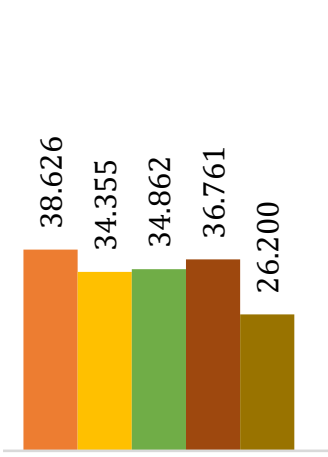

3

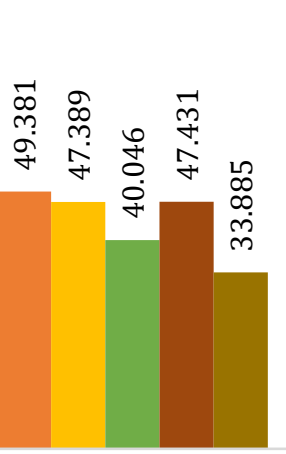

7

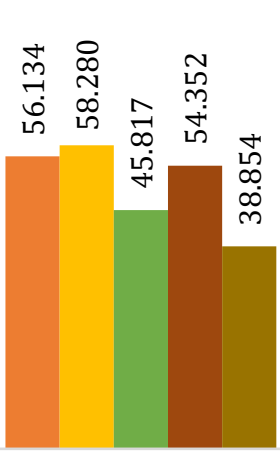

14

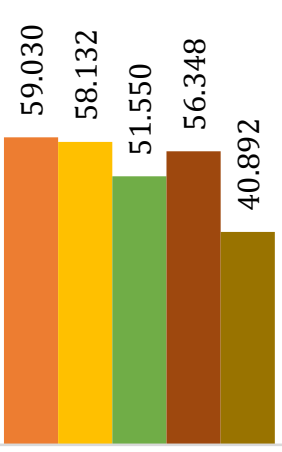

21

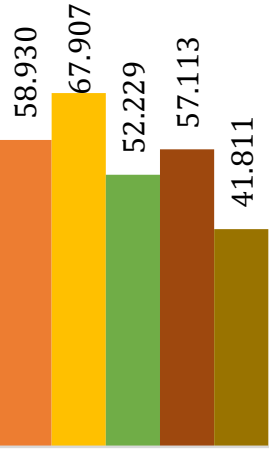

28

$\square$ Semen Holcim $\quad$ Semen Conch $\quad$ Semen Tiga Roda $\quad$ Semen Gresik $\quad$ Semen Puger

FIGURE 7: The average relationship of the Modulus of Elasticity

\section{Split Tensile Strength Test}

The tensile strength value is obtained by entering the maximum value when the test object is destroyed and split into 2 parts.

TABLE 14: RPC Concrete Split Tensile Strength Data

\begin{tabular}{|c|c|c|}
\hline No & Sample & $\begin{array}{c}\text { Average Split Tensile } \\
\text { Strength (MPa) }\end{array}$ \\
\hline 1 & V1 (PCC Holcim) & $36,079.963$ \\
\hline 2 & V2 (PCC Conch) & $38,730.681$ \\
\hline 3 & V3 (PCC 3 Roda) & $33,966.728$ \\
\hline 4 & V4 (PCC Gersik) & $35,519.377$ \\
\hline 5 & V5 (PPC Puger) & $30,390.870$ \\
\hline
\end{tabular}

From the table it can be seen that the RPC concrete of each variation was taken from the 3 samples that had been made, which resulted in an average split tensile strength of 28 days between $25.087-40.340 \mathrm{MPa}$. From the results obtained, the largest split tensile strength is variation 2 using the PCC type cement brand, while the lowest is variation 5 using the PPC type cement brand. From the results obtained, it turns out that the split tensile strength of RPC concrete is greater than normal concrete, namely from $54.84 \%$ - $60 \%$ of its compressive strength, while normal concrete is $10 \%-15 \%$ of normal concrete compressive strength.

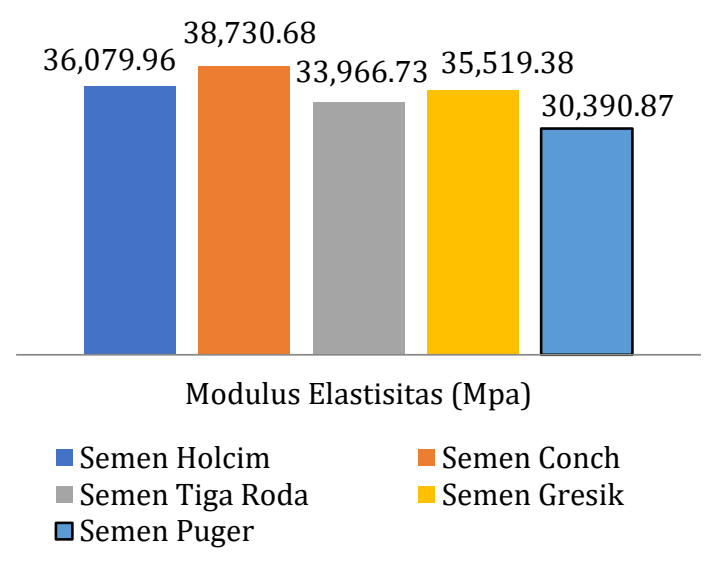

FIGURE 8: Tensile strength average relationship

\section{CONCLUSIONS}

Based on the analysis of the research results, several conclusions can be drawn as follows:

1. The average compressive strength for the age of 28 days is between 41.811 - $67.907 \mathrm{MPa}$. From the results obtained, the greatest compressive strength is variation 2 using the PCC type cement brand, while the lowest is variation 5 using the PPC type cement brand. The compressive strength of RPC concrete from the age of 3 days to 28 days experienced an increase in its compressive strength along with the age of the RPC concrete.

2. The compressive strength of the plan is $52 \mathrm{MPa}$, so from the resulting compressive strength it can be concluded that the compressive strength that reaches according to the plan is RPC concrete for variations 1 to 4 , which uses the PCC type cement brand. 
3. RPC concrete produces an average split tensile strength of 28 days between 25.087-40.340 MPa. From the results obtained, the largest split tensile strength is variation 2 using the PCC type cement brand, while the lowest is variation 5 using the PPC type cement brand. From the results obtained, it turns out that the split tensile strength of RPC concrete is greater than normal concrete, namely from $54.84 \%-60 \%$ of its compressive strength, while normal concrete is $10 \%$ $15 \%$ of normal concrete compressive strength.

4. Judging from the results obtained, the best (optimum) brand of cement is the PCC Conch in terms of its physical and mechanical properties.

\section{ACKNOWLEDGMENT}

Thank you to the Faculty of Engineering Tanjungpura University Pontianak, West Kalimantan has supported, funding and all parties involved in this research.

\section{REFERENCES}

[1] Candrlic, V., Concrete arch bridge over Bakar straits. Proceedings for Conference of Croatian builders, eds. V. Simovic, Cavtat, pp. 358-364.,2001.

[2] Jagar, A., High performance concrete, Faculty of civil engineering: Zagreb,2003.

[3] Edward Nawy, G., Fundamentals of high-performance concrete, John Wiley\& Sons: New York, 2001.

[4] Cizmar, D., Mestrovic D., Radic, J., "Arch bridge made of reactive powder oncrete”, HPSM 2006, Ostend, 2006.

[5] American Concrete Institute Committee 544, (1982) "State of The Art Report on Fiber Reinforced Concrete",Detroit: American Concrete Institute.

[6] ASTM C1018, (2002). "Standard Test Method for Flexural Toughness and First-Crack Strength of FiberRefinforced Concrete (Using Beam with Third-Point Loading)", Annual Book of ASTM Standard, vol 04.02, American Society for Testing and Materials, Philadelphia, pp. 546-553.
[7] ASTM C78, (2002). "Standard Test Method for Flexural Strength of Concrete", (Using Simple Beams with Third-Point Loading Annual Book of ASTM Standard, vol 04.02, American Society for Testing and Materials,Philadelphia, pp. 35-37.

[8] ASTM C995, (2002). "Standard Test Method for Time of Flow of Fiber-Reinforced Concrete Through Inverted Slump Cone", Annual Book of ASTM Standard, vol 04.02,

[9] American Society for Testing and Materials,Philadelphia, pp. 536-537.Bentur, A. \& Mindess, S.(1990), " Fibre Reinforced Cementitious Composites". Elsevier Applied Science, NewYork.

[10] Ju Yang, Liu Hong Bin, Chen Jian, Jia Yu Dan, Peng Pei Huo, (2009). " Toughness and haracterization of Reactive Powder Concrete with Ultra-High Strength", Science in China Series E - Technological Science.Vol. 52, No. 4. April 2009. pp. 1000-1018.

[11] Kim Huy Hoang, Hyunh Ba Phat, Le Viet Duc Hien, Nguyen Van Chanh. (2008). " Influence of Types of Steel Fiberon Properties of Ultra High-Performance Concrete", The 3rd ACF International Conference. pp. 347-355.

[12] R.B., Khadiranaikar and S.M., Muranal (2012). "Factors Affecting the Strength Of Reactive Powder Concrete (RPC)", International Journal Of Civil Engineering And Technology (IJCIET)Volume 3, Issue 2, July-December (2012), Pp. 455-464.

[13] Richard, P. \& Cheyrezy, M. (1995). "Composition of Reactive Powder Concretes". Cement Concrete Research Vol.25 No.7, pp. 1501-1511.

[14] SNI-03-1974, (1990). "Metode Pengujian Kuat Tekan Beton”, Badan Standarisasi Nasional, Jakarta.

[15] SNI-1970, (2008). "Cara Uji Berat Jenis dan Penyerapan Air Agregat Halus", Badan Standarisasi Nasional,Jakarta. 